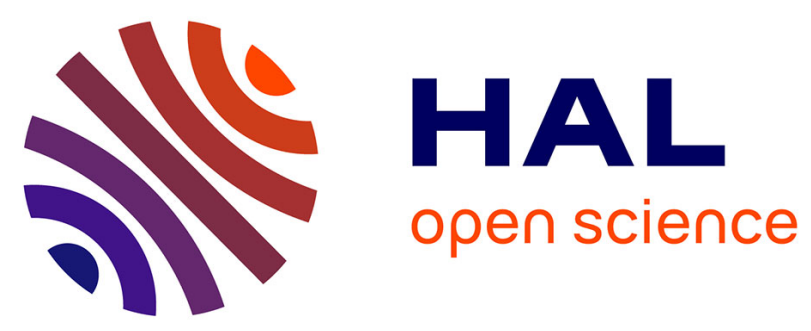

\title{
Saliva as a non-invasive tool for monitoring oxidative stress in swimmers athletes performing a VO2max cycle ergometer test
}

Denise Biagini, Tommaso Lomonaco, Silvia Ghimenti, Jonathan Fusi, Eugenio Cerri, Francesca de Angelis, Francesca G Bellagambi, Camille Oger, Jean Marie Galano, Emilia Bramanti, et al.

\section{To cite this version:}

Denise Biagini, Tommaso Lomonaco, Silvia Ghimenti, Jonathan Fusi, Eugenio Cerri, et al.. Saliva as a non-invasive tool for monitoring oxidative stress in swimmers athletes performing a VO2max cycle ergometer test. Talanta, 2020, 216, pp.120979. 10.1016/j.talanta.2020.120979 . hal-02617520

\author{
HAL Id: hal-02617520 \\ https://hal.science/hal-02617520
}

Submitted on 3 Jun 2021

HAL is a multi-disciplinary open access archive for the deposit and dissemination of scientific research documents, whether they are published or not. The documents may come from teaching and research institutions in France or abroad, or from public or private research centers.
L'archive ouverte pluridisciplinaire HAL, est destinée au dépôt et à la diffusion de documents scientifiques de niveau recherche, publiés ou non, émanant des établissements d'enseignement et de recherche français ou étrangers, des laboratoires publics ou privés. 


\title{
Saliva as a non-invasive tool for monitoring oxidative stress in swimmers athletes performing a $\mathrm{VO}_{2 \max }$ cycle ergometer test
}

\author{
Denise Biagini $^{\mathrm{a}}$, Tommaso Lomonaco ${ }^{\mathrm{a}, *}$, Silvia Ghimenti ${ }^{\mathrm{a}}$, Jonathan Fusi ${ }^{\mathrm{b}}$, Eugenio Cerri $^{\mathrm{b}}$, \\ Francesca De Angelis ${ }^{\mathrm{a}}$, Francesca Giuseppa Bellagambi ${ }^{\mathrm{c}}$, Camille Oger ${ }^{\mathrm{d}}$, Jean Marie Galano ${ }^{\mathrm{d}}$, \\ Emilia Bramanti ${ }^{\mathrm{e}}$, Ferdinando Franzoni ${ }^{\mathrm{b}}$, Roger Fuoco ${ }^{\mathrm{a}}$, Fabio Di Francesco ${ }^{\mathrm{a}}$ \\ a Department of Chemistry and Industrial Chemistry, University of Pisa, Via Giuseppe Moruzzi 13, 56124, Pisa, Italy \\ ${ }^{\mathrm{b}}$ Department of Clinical and Experimental Medicine, University of Pisa, Via Roma 67, 56124, Pisa, Italy \\ ${ }^{\mathrm{c}}$ Univ Lyon, CNRS, Université Claude Bernard Lyon 1, Institut de Sciences Analytiques, UMR 5280, 5 rue de la Doua, F-69100, Villeurbanne, France \\ ${ }^{\mathrm{d}}$ Institut des Biomolécules Max Mousseron, IBMM, Université de Montpellier, CNRS, ENSCMFaculté de Pharmacie, 15 avenue Charles Flahault, BP 14491, F-34093, \\ Montpellier Cedex 05, France \\ ${ }^{\mathrm{e}}$ Institute of Chemistry of Organometallic Compounds, CNR, Via Giuseppe Moruzzi 3, 56124, Pisa, Italy
}

A R T I C L E IN F O

\section{Keywords:}

Saliva

Prostanoids

Isoprostanes

Carbonyl compounds

Oxidative stress

$\mathrm{VO}_{2 \max }$ cycle ergometer test

\begin{abstract}
A B S T R A C T
Biomarkers of oxidative stress are generally measured in blood and its derivatives. However, the invasiveness of blood collection makes the monitoring of such chemicals during exercise not feasible. Saliva analysis is an interesting approach in sport medicine because the collection procedure is easy-to-use and does not require specially-trained personnel. These features guarantee the collection of multiple samples from the same subject in a short span of time, thus allowing the monitoring of the subject before, during and after physical tests, training or competitions. The aim of this work was to evaluate the possibility of following the changes in the concentration of some oxidative stress markers in saliva samples taken over time by athletes under exercise. To this purpose, ketones (i.e. acetone, 2-butanone and 2-pentanone), aldehydes (i.e. propanal, butanal, and hexanal), $\alpha, \beta$-unsaturated aldehydes (i.e. acrolein and methacrolein) and di-carbonyls (i.e. glyoxal and methylglyoxal) were derivatized with 2,4-dinitrophenylhydrazine, and determined by ultra-high performance liquid chromatography coupled to diode array detector. Prostaglandin $\mathrm{E}_{2}, \mathrm{~F}_{2} / \mathrm{E}_{2}$-isoprostanes, $\mathrm{F}_{2}$-dihomo-isoprostanes, $\mathrm{F}_{4}$ neuroprostanes, and $\mathrm{F}_{2}$-dihomo-isofuranes were also determined by a reliable analytical procedure that combines micro-extraction by packed sorbent and ultra-high performance liquid chromatography-electrospray ionization tandem mass spectrometry. Overall the validation process showed that the methods have limits of detection in the range of units of ppb for carbonyls and tens to hundreds of ppt for isoprostanes and prostanoids, very good quantitative recoveries (90-110\%) and intra- and inter-day precision lower than 15\%. The proof of applicability of the proposed analytical approach was investigated by monitoring the selected markers of oxidative stress in ten swimmers performing a $\mathrm{VO}_{2 \max }$ cycle ergo meter test. The results highlighted a clear increase of salivary by-products of oxidative stress during exercise, whereas a sharp decrease, approaching baseline values, of these compounds was observed in the recovery phase. This study opens up a new approach in the evaluation of oxidative stress and its relation to aerobic activity.
\end{abstract}

\section{Introduction}

Free radicals are usually produced as part of normal metabolic processes to modulate cell signaling and vital physiological functions $[1,2]$. The cellular redox homeostasis is guaranteed by the presence of scavenging defense systems that minimize the excess of free radicals [3]. However, an imbalance between antioxidant defenses and production of free radicals causes a condition called oxidative stress (OS) that induces cell and tissue damages [4]. Oxidative stress has different pathophysiological impacts on biological processes, exacerbating several diseases such as diabetes [5] and cardiovascular disease [6]. The most important free radicals in living cells are reactive oxygen species (ROS) and reactive nitrogen species (NOS), both of them are involved in biological reactions with lipids and proteins [7]. The in vivo detection of these free radicals is challenging due to their very short half-life (e.g. $\cdot \mathrm{OH} \sim 10^{-9} \mathrm{~s}$ ) $[8,9]$. Thus, the monitoring of OS normally involves the

\footnotetext{
* Corresponding author.

E-mail address: tommaso.lomonaco@unipi.it (T. Lomonaco).
} 
determination of sub-products of lipid peroxidation in blood, such as aldehydes (e.g. methylglyoxal, diacetyl, acrolein, crotonaldehyde, and hexanal $[10,11])$ and prostaglandin $\mathrm{F}_{2}$-like compounds that are produced in vivo by non-enzymatic free radical-catalyzed peroxidation of arachidonic acid [12].

In order to counteract the effects of oxidative stress, the scientific community has commonly accepted the concept that performing a regular physical activity of moderate intensity brings significant health benefits, including prevention and treatment of chronic diseases [13-15]. Among the molecular mechanisms related to these beneficial effects, an enhancement of antioxidant defenses and a drop of lipid peroxidation have been evidenced both in adult and in aged individuals [16]. Nevertheless, prolonged and intense exercise can result in free radicals (over)production leading to an impairment of the antioxidant defenses of humans and a consequent modification of the cellular components. In this regard, ROS and NOS may oxidize proteins provoking a change of their tridimensional structure that may limit in turn the functional activities, including gene transcription [17]. The oxidation of polyunsaturated free fatty acids and lipoproteins induces changes in fluidity and permeability of the cell membrane [18]. It impairs physical performance by altering contractile function and/or accelerating muscle damage/fatigue [19], and may lead to a vicious cycle of ROS generation and DNA damage [20]. This scenario is further exacerbated by the cytotoxic effect of endogenous aldehydes, e.g. acrolein, methylglyoxal, and crotonaldehyde [21]. Recent studies have been focused on isoprostanes as markers of oxidative stress after exercise [22]. $\mathrm{F}_{2}$-isoprostanes ( $\mathrm{F}_{2}$-IsoPs) were found to increase in athletes during extreme endurance exercise and in ultra-marathon runners [23,24]. Moreover, specific markers of oxidative damage to the brain belonging to new families of isoprostanes, such as $\mathrm{F}_{2}$-dihomo-Isoprostanes $\left(\mathrm{F}_{2}\right.$-dihomo-IsoPs) and $\mathrm{F}_{4}$-neuroprostanes ( $\mathrm{F}_{4}$-NeuroPs) have been recently reported in literature. They originate from the free radical peroxidation of adrenic and docosahexanoic acid, respectively, and showed a significant change of the urine level as a results of increasing or decreasing training loads. A decrease of these markers associated to neuronal membrane degradation was observed in urine using polyphenols-rich juice as antioxidant supplementation to triathletes $[25,26]$.

Athletes may take vitamin-based supplements after a race to limit oxidative damage, even if it is not clear if the body's natural antioxidant defense system is sufficient to balance the increase of free radicals [27]. In this case, a personalized and targeted antioxidant supplementation, tuned with respect to the resistance of each athlete to the attack of free radicals, should guarantee the correct counterbalance between anti-/ pro-oxidants, and improving athlete recovery to reduce cellular damage and maintaining peak athletic performance.

Few articles have reported saliva analysis as an alternative source of useful information in physiological research related to the performance of sports teams [28-31]. In the last decades, the monitoring of human health conditions using non-invasive fluids analysis (e.g. breath, saliva, and sweat) in alternative to traditional blood and urine assays has attracted increasing attention in the field of medical diagnosis [32-35] and therapy monitoring [36,37]. In particular, saliva analysis may provide a comprehensive characterization of exercise-related oxidative stress markers thanks to the rapid equilibrium between blood and saliva across salivary membranes [38]. Moreover, the use of saliva to monitor oxidative stress during the physical exercise is an attractive approach because it shows several advantages compared to blood and its derivatives: i) non-invasive collection procedures, ii) no need for trained personnel to collect the sample, iii) low risk of infections, and iv) simpler chemical composition compared to blood and its derivatives $[39,40]$. Most of these features make the collection of several saliva samples in a pre-determined time span from one subject very easy, particularly appealing in the field of physical tests, training or competitions. In this regard, the concomitant monitoring of a comprehensive panel of by-products related to the oxidative stress might provide a more informative picture of the process under investigation, enabling a better understanding of the physiopathology and its implication in physical exercise.

The aim of this work was to evaluate saliva analysis as a non-conventional innovative analytical approach to monitor oxidative stress during physical exercise. For this purpose, reliable analytical procedures for the determination of selected markers of the oxidative damage, i.e. carbonyls, isoprostanes, and prostanoids, in stimulated saliva samples were developed and validated. Finally, the procedures were applied to saliva samples collected from 10 swimmers athletes performing a cycle ergometer test for the determination of the maximal aerobic capacity $\left(\mathrm{VO}_{2 \max }\right)$.

\section{Materials and methods}

\subsection{Chemicals and materials}

2,4-dinitrophenilhydrazine (2,4-DNPH, purity of 97\%), TO11/IP-6A Aldehyde/Ketone-DNPH Mix $(15 \mu \mathrm{g} / \mathrm{mL}$ of acetaldehyde-2,4-DNPH, acetone-2,4-DNPH, acrolein-2,4-DNPH, benzaldehyde-2,4-DNPH, butyraldehyde-2,4-DNPH, crotonaldehyde-2,4-DNPH, 2,5-dimethylbenzaldehyde-2,4-DNPH, formaldehyde-2,4-DNPH, hexaldehyde-2,4-DNPH, isovaleraldehyde-2,4-DNPH, propionaldehyde2,4-DNPH, o-tolualdehyde-2,4-DNPH, m-tolualdehyde-2,4-DNPH, ptolualdehyde-2,4-DNPH, valeraldehyde-2,4-DNPH), acetone (purity $\geq 99.9 \%$ ), 2-butanone (purity $\geq 99.9 \%$ ), 2-pentanone (purity $\geq 99.9 \%$ ), propanal (purity $\geq 99.9 \%$ ), butanal (purity $\geq 99.9 \%$ ), hexanal (purity $\geq 99.9 \%$ ), acrolein (purity $\geq 99.9 \%$ ), methacrolein (purity $\geq 99.9 \%$ ), glyoxal (purity of $40 \%$ ), methylglyoxal (purity of $40 \%$ ), magnesium sulfate (purity $\geq 99.5 \%$ ), formic acid (purity of $98 \%$ ), ammonium acetate (purity $\geq 99.9 \%$ ), and ammonium formate (purity $\geq 99.9 \%$ ) where purchased from Sigma Aldrich (Milan, Italy). Water, acetonitrile, and methanol where purchased from Sigma Aldrich (Milan, Italy) at LC/MS grade.

Commercially available prostaglandin $\mathrm{E}_{2}\left(\mathrm{PGE}_{2}\right), \mathrm{F}_{2^{-}}$and $\mathrm{E}_{2}$-isoprostanes (IsoPs), $15-\mathrm{F}_{2 \mathrm{t}}$-IsoP and $15-\mathrm{E}_{2 \mathrm{t}}$-IsoP (purity $\geq 99 \%$ ) were from Cayman Chemical (Michigan, USA).

Not commercially available $\mathrm{F}_{4}-\mathrm{NeuroPs}\left(20-\mathrm{F}_{4 \mathrm{t}}-\mathrm{NeuroP}, 20-e p i-\mathrm{F}_{4 \mathrm{t}^{-}}\right.$ NeuroP), $\mathrm{F}_{2}$-dihomo-IsoPs (ent-7(R,S)-7- $\mathrm{F}_{2 \mathrm{t}}$-dihomo-IsoP, 17- $\mathrm{F}_{2 \mathrm{t}}$-dihomo-IsoP) and $\mathrm{F}_{2}$-dihomo-IsoF $\left(7(\mathrm{R}, \mathrm{S})\right.$-ST- $\Delta^{8}$-11-dihomo-IsoF) were synthesized at the Institut des Biomolecules Max Mousseron (IBMM) (Montpellier, France) according to procedures reported elsewhere [41-44].

All the solutions and saliva samples were stored in sterile polypropylene containers from Eppendorf (Milan, Italy).

Phenex $^{\mathrm{TM}}$-RC syringe filters $(0.2 \mu \mathrm{m}$ regenerate cellulose, 4 and $15 \mathrm{~mm}$ of diameter) were from Phenomenex (California, USA).

The $\mathrm{eVol}^{\circledast} \mathrm{XCHANGE}^{\mathrm{X}}$ analytical syringe $(20-500 \mu \mathrm{L})$ and microextraction by packed sorbent silica-C18 Barrel Insert and Needles (BINs) were purchased from SGE Analytical Science (Melbourne, Australia).

Salivette roll-shaped polyester swabs were purchased from Sarstedt (Nümbrecht, Germany).

A Macherey Nagel Pehanon narrow range $(5.2<\mathrm{pH}<8.1) \mathrm{pH}$ paper strips (Düren, Germany) with a resolution of $0.3 \mathrm{pH}$ units was used to estimate the salivary $\mathrm{pH}$.

An Amicon Ultra-0.5 mL Centrifugal Filters (Darmstadt, Germany) with a cut-off of $3 \mathrm{kDa}$ was used to purify saliva samples.

\subsection{Equipment}

A VELP Scientifica ZX4 Advanced Vortex Mixer (Usmate, Italy) and an Eppendorf 5804 R Centrifuge, equipped with an A-4-44 swinging bucket rotor (Milan, Italy), were used for sample vortex-mixing and centrifugation, respectively. The derivatization reaction was carried out using a Julabo SW22 thermostatic water bath (Milan, Italy), which guarantees an accurate control of the temperature (resolution of $0.1^{\circ} \mathrm{C}$ ). 
A Radwag AS220/X balance (Milan, Italy) was used to weight Salivette swabs before and after sampling.

An Agilent 1290 Infinity II LC system coupled to an Agilent 1290 diode array detector (DAD) was used for the determination of 2,4DNPH adducts. The chromatographic separation was carried out using a Zorbax Eclipse plus reversed-phase column $(50 \times 2.1 \mathrm{~mm}, 1.8 \mu \mathrm{m})$ coupled to a guard column $(5 \times 2.1 \mathrm{~mm}, 1.8 \mu \mathrm{m})$, both from Agilent Technologies (Santa Clara, USA). The UHPLC-DAD instrument was controlled by OpenLAB software (v. A.01.05) from Agilent Technologies (Santa Clara, USA).

An Agilent 1290 Infinity II LC system coupled to an Agilent 6495 triple quadrupole mass spectrometer detector was used for the determination of isoprostanes and prostanoids. The chromatographic separation was carried out using a Polaris 3 C-18 reverse-phase column $(50 \times 4.6 \mathrm{~mm}, 3 \mu \mathrm{m})$ coupled to a guard column $(5 \times 4.6 \mathrm{~mm}, 3 \mu \mathrm{m})$, both from Agilent Technologies (Santa Clara, USA). The UHPLC-MS/MS instrument was controlled by MassHunter software (v. B.07.01) from Agilent Technologies (Santa Clara, USA).

\subsection{Standard solutions and quality control samples}

Working solutions of TO11/1P-6A mixture were prepared gravimetrically by diluting 100-, 20-, 10- and 2-fold the stock solution $(15 \mu \mathrm{g} / \mathrm{mL})$ with a mixture of acetonitrile and water $(70: 30 \% \mathrm{v} / \mathrm{v})$ and then stored in amber vials at $4{ }^{\circ} \mathrm{C}$ for one week.

Stock solution of ketones (i.e. acetone, 2-butanone and 2-pentanone), aldehydes (i.e. propanal, butanal, and hexanal), $\alpha, \beta$-unsaturated aldehydes (i.e. acrolein and methacrolein) and di-carbonyls (i.e. glyoxal and methylglyoxal) were prepared gravimetrically by dissolving $5 \mu \mathrm{L}$ of each pure compound in $10 \mathrm{~mL}$ of acetonitrile. All stock solutions were prepared every week and then stored in amber vials at $4{ }^{\circ} \mathrm{C}$. Working mixtures were prepared daily by diluting 8000-, 3000-, 1600-fold the stock solutions with water to obtain different concentration levels of target compounds.

Stock solutions of 2,4-DNPH $(12 \mathrm{mM})$ were prepared gravimetrically by dissolving $25 \mathrm{mg}$ of the pure compound in $10 \mathrm{~mL}$ of acetonitrile and stored in amber vials at $4{ }^{\circ} \mathrm{C}$ for one week. The solution was acidified by adding $0.2 \mathrm{~mL}$ of formic acid.

Stock solutions of $15-\mathrm{F}_{2 \mathrm{t}}$-IsoP, $\mathrm{PGE}_{2}$ and $15-\mathrm{E}_{2 \mathrm{t}}$-IsoP $(1000 \mu \mathrm{g} / \mathrm{mL})$ were prepared by dissolving $1 \mathrm{mg}$ of pure compound in $1 \mathrm{~mL}$ of a mixture of acetonitrile and methanol $(50: 50 \mathrm{v} / \mathrm{v})$. These solutions were protected from light and stored at $-20{ }^{\circ} \mathrm{C} .1000 \mu \mathrm{g} / \mathrm{mL}$ stock solutions of the remaining isoprostanes were prepared in methanol at Institut des Biomolécules Max Mousseron (Montpellier, France) and shipped in dry ice to our lab. Once arrived, they were immediately stored at $-20{ }^{\circ} \mathrm{C}$, and used to prepare monthly intermediate stock solutions of the analytes at $10 \mu \mathrm{g} / \mathrm{mL}$ in a 50:50 v/v acetonitrile:methanol mixture. A standard solution containing all the analytes at $10 \mathrm{ng} / \mathrm{mL}$ concentration level (MIX) was prepared weekly through sequential dilutions of each stock solution with LC-MS water and then stored at $4{ }^{\circ} \mathrm{C}$. This solution was used to prepare working standard solutions and quality control samples in the range $0.05-1 \mathrm{ng} / \mathrm{mL}$.

Stock solutions of internal standards (i.e. 8-isoPGF $2 \alpha^{-}$d4, 8-isoPGE $2_{2}$ $\mathrm{d} 4$ and $\left.\mathrm{PGE}_{2}-\mathrm{d} 4\right)$ were supplied in methyl acetate at $100 \mu \mathrm{g} / \mathrm{mL}$ concentration level and stored at $-20{ }^{\circ} \mathrm{C}$. A working standard mixture at $20 \mathrm{ng} / \mathrm{mL}$ (MIX ISs) was prepared weekly through sequential dilutions with LC-MS water from the stock solutions and stored at $4{ }^{\circ} \mathrm{C}$.

Pooled saliva samples were obtained by mixing known aliquots of stimulated saliva samples collected from 10 nominally healthy control volunteers that did not performed the exercise test. This pooled sample was daily spiked with known amounts of analytes to obtain standard saliva samples at different quality control levels.

\subsection{Exercise protocol and sample collection}

Ten swimmers (6 males and 4 females) performed an incremental
Table 1

Age, height, weight, body mass index (BMI), maximal oxygen consumption $\left(\mathrm{VO}_{2 \max }\right)$, and maximal working capacity (MWC) of the enrolled swimmers athletes $(\mathrm{n}=10)$.

\begin{tabular}{ll}
\hline Characteristics & $\begin{array}{l}\text { Value } \\
\text { (mean } \pm \text { standard deviation) }\end{array}$ \\
\hline Age $(\mathrm{y})$ & $23 \pm 5$ \\
Height $(\mathrm{cm})$ & $178 \pm 8$ \\
Weight $(\mathrm{Kg})$ & $71 \pm 7$ \\
$\mathrm{BMI}\left(\mathrm{Kg} / \mathrm{m}^{2}\right)$ & $22 \pm 2$ \\
$\mathrm{VO}_{2 \max }(\mathrm{mL} / \mathrm{Kg} \min )$ & $49 \pm 7$ \\
$\mathrm{MWC}(\mathrm{W})$ & $270 \pm 40$ \\
\hline
\end{tabular}

cycle ergometer exercise test of maximal aerobic power in order to estimate the $\mathrm{VO}_{2 \max }$ [45]. The study was conducted at the "Dipartimento di Medicina Clinica e Sperimentale" of the University of Pisa in accordance with the Declaration of Helsinki. All subjects provided written informed consent before starting the experiments. Eating habits of swimmers were evaluated using a questionnaire. They followed a Mediterranean diet characterized by $50 \%$ carbohydrates, $30 \%$ proteins, and $20 \%$ fats. All subjects were non-smokers and did not take any supplements.

Table 1 reports the anthropometric characteristics of the enrolled swimmers athletes.

The exercise test was performed by an electrically braked cycle ergometer (Quark PFT ergo, COSMED, Italy). The workload was $25 \mathrm{~W}$ for the first $5 \mathrm{~min}$ followed by an increase of $25 \mathrm{~W}$ every minute until impossibility to maintain the pace due to fatigue. The evaluation of fatigue was done according to the Borg Scale [46]. During exercise, pedaling cadence was constant at $70 \mathrm{rpm}$. Stimulated saliva samples were collected by moving the swab in the mouth for $1 \mathrm{~min}$ at the following times: $5 \mathrm{~min}$ before the test $\left(\mathrm{t}_{0}\right)$, at the maximal exercise peak $\left(\mathrm{t}_{1}\right), 2.5\left(\mathrm{t}_{2}\right), 5 \mathrm{~min}\left(\mathrm{t}_{3}\right)$ and $10\left(\mathrm{t}_{4}\right)$ minutes after the $\mathrm{VO}_{2 \max }$. The timing of the experiment (3:00 p.m. to 5:00 p.m.) was chosen to minimize the influence of circadian variation in salivary composition [47]. Respiratory quotient is calculated as the ratio between the volume of carbon dioxide released over the volume of oxygen absorbed during respiration [48]. Samples were recovered by centrifuging the swabs at $5000 \mathrm{rpm}$ for $5 \mathrm{~min}$ at $4{ }^{\circ} \mathrm{C}$ and stored at $-80{ }^{\circ} \mathrm{C}$ until the analysis. Immediately after sampling, two independent measurements of the salivary $\mathrm{pH}$ were performed by using $\mathrm{pH}$ paper strips. The salivary flow rate (grams per minute) was calculated from the ratio of sample weight and collection time, assuming a unit density for saliva [49].

\subsection{Sample analysis}

Method 1: an aliquot of saliva sample $(0.2 \mathrm{~mL})$ was transferred into an Amicon tube and centrifuged at $12500 \mathrm{rpm}$ for $25 \mathrm{~min}$ at $4{ }^{\circ} \mathrm{C}$. The derivatization reaction was carried out using a modified version of Andreoli's procedure [50]. Briefly, an aliquot $(0.1 \mathrm{~mL})$ of ultrafiltrate was added to the Eppendorf tube together with $0.1 \mathrm{~mL}$ of 2,4-DNPH $(12 \mathrm{mM})$ and incubated at $30.0 \pm 0.1{ }^{\circ} \mathrm{C}$ for $60 \mathrm{~min}$. This solution was then filtered with a RC syringe filter ( $4 \mathrm{~mm}$ diameter, $0.2 \mu \mathrm{m}$ pore size) and injected $(20 \mu \mathrm{L})$ into the UHPLC-DAD system. Chromatographic separation was carried out at $0.5 \mathrm{~mL} / \mathrm{min}$ using a water (A)/acetonitrile (B) mobile phase. The following gradient was used: isocratic for $2 \mathrm{~min}$ $(A / B=70 / 30)$, followed by an increase of acetonitrile up to $65 \%$ in $17 \mathrm{~min}$. The column was rinsed with a mixture of A (10\%) and B (90\%) for $4 \mathrm{~min}$ followed by a re-equilibration step (30\% of B) of $7 \mathrm{~min}$. The UHPLC run time was $30 \mathrm{~min}$. The Agilent 1290 high performance wellplate autosampler and the 1290 thermostatted column compartment was set at $4{ }^{\circ} \mathrm{C}$ and $30{ }^{\circ} \mathrm{C}$, respectively. Before every injection, needle was washed for $60 \mathrm{~s}$ with a water-acetonitrile mixture $(80: 20, \mathrm{v} / \mathrm{v})$. Acetone, 2-butanone, 2-pentanone, propanal, butanal, hexanal, acrolein, methacrolein and benzaldehyde were monitored acquiring the 
signal at $370 \mathrm{~nm}$, crotonaldehyde, cyclohexanone and pentanal at $380 \mathrm{~nm}$ and glyoxal and methylglyoxal at $420 \mathrm{~nm}$. For each signal, bandwidth and reference wavelength were set at $\pm 5 \mathrm{~nm}$ and at $550 \pm 20 \mathrm{~nm}$, respectively. The DAD spectrum was acquired from 200 to $600 \mathrm{~nm}$, with a scan rate of 20 scans/s.

Method 2: saliva sample extraction was performed by a modified version of a method previously described [51]. Briefly, an aliquot of saliva $(0.5 \mathrm{~mL})$ was added with $0.01 \mathrm{~mL}$ of MIX ISs $(20 \mathrm{ng} / \mathrm{mL})$ and then diluted to $3 \mathrm{~mL}$ with LC-MS water. The diluted saliva sample was vortex mixed for $30 \mathrm{~s}$, filtered with a RC syringe filter (15 mm diameter, $0.2 \mu \mathrm{m}$ pore size) and then subjected to microextraction by packed sorbent (MEPS) procedure prior to UHPLC-MS/MS analysis. The MEPS procedure was performed through an off-line semi-automated system, assembled in our lab, combining the $\mathrm{eVol}^{\circledR} \mathrm{XCHANGE}$ analytical syringe (20-500 $\mu \mathrm{L}$, SGE Analytical Science, UK) and the AL-4000 Programmable Syringe Pump (World Precision Instrument, USA). The cartridge was activated and then conditioned by drawing and discharging three times an aliquot $(100 \mu \mathrm{L})$ of methanol and water, respectively. After that, $500 \mu \mathrm{L}$ of the diluted sample were loaded up and discharged six times in order to retain isoprostanes and prostanoids. The cartridge was then washed one time with an aliquot $(100 \mu \mathrm{L})$ of a water:methanol mixture $(95: 5 \mathrm{v} / \mathrm{v})$ to remove potential interferences and to minimize the matrix effect. Finally, the analytes were eluted from the cartridge with $50 \mu \mathrm{L}$ of pure methanol. Sampling and elution were performed at $0.3 \mathrm{~mL} / \mathrm{min}$, whereas all the other steps at $0.6 \mathrm{~mL} / \mathrm{min}$. An aliquot $(20 \mu \mathrm{L})$ of the extract was injected into the UHPLC-MS/MS instrument for the analysis. Chromatographic separation was carried out at $0.7 \mathrm{~mL} /$ min using a $0.1 \%$ aqueous formic acid (A)/50:50 methanol:acetonitrile (B) mobile phase. The following gradient was used: isocratic for $2 \mathrm{~min}$ (A/B $=90 / 10$ ), then $45 \%$ (B) at $2.1 \mathrm{~min}$, isocratic for $3 \mathrm{~min}$, up to $60 \%$ (B) in $3.5 \mathrm{~min}$, isocratic for $0.5 \mathrm{~min}, 80 \%$ (B) at $9 \mathrm{~min}$, isocratic for $5 \mathrm{~min}$, re-equilibration to initial conditions up to $18 \mathrm{~min}$. The multisampler and the column compartment were set at a $4{ }^{\circ} \mathrm{C}$ and $25{ }^{\circ} \mathrm{C}$, respectively. The mass spectrometer operated in ESI negative ionization mode and performed multiple reaction monitoring (MRM) experiments with unit mass resolution, monitoring at least two transitions for each compound. For all analytes, the ESI operation conditions were: drying gas temperature $240{ }^{\circ} \mathrm{C}$, drying gas flow $18 \mathrm{~L} / \mathrm{min}$, nebulizer gas pressure $30 \mathrm{psi}$, sheath gas temperature $360^{\circ} \mathrm{C}$, sheath gas flow $12 \mathrm{~L} /$ min, capillary voltage $5000 \mathrm{~V}$ and nozzle $1500 \mathrm{~V}$. The fragmentor voltage was fixed at $380 \mathrm{~V}$ and high and low pressure funnel voltages were set at $160 \mathrm{~V}$ for all mass transitions. Each analyte was detected using two specific MRM transitions, the most abundant was used for quantification $(Q)$, whereas the second one for the identification of the target compound (q). A deviation of $\pm 0.10 \mathrm{~min}$ of the expected retention time compared to working standard solutions and a qualifier/ quantifier $(\mathrm{q} / \mathrm{Q})$ ratio within $10 \%$ of the ratio measured in working standard mixtures were required for analyte identification [52].

\subsection{Methods validation and statistical analysis}

The analytical method validation was performed in accordance with the IUPAC guidelines [53] and included the evaluation for each analyte of limit of detection (LOD) and quantification (LOQ), calibration curve, matrix effect, recovery, intra-day and inter-day precision.

LOD and LOQ values were calculated as three and ten times the standard deviation (sb) of the "low level spiked blank" with carbonyls $(5 \mathrm{ng} / \mathrm{mL})$, isoprostanes and prostanoids $(0.05 \mathrm{ng} / \mathrm{mL})$. These samples were analyzed five times.

Five-point calibration curves ( $\mathrm{n}=3$ at each concentration level) were obtained in the range $25-250 \mathrm{ng} / \mathrm{mL}$ for carbonyls and $0.05-1 \mathrm{ng}$ / $\mathrm{mL}$ for isoprostanes and prostanoids. Optimal equation curves were evaluated by the Deming regression analysis, which considers measurement errors for both dependent and independent variables [54].

The recovery, precision and matrix effect of the analytical procedures were evaluated by analyzing in triplicate ( $n=3$ at each concentration level) within the same day and on three consecutive days a pooled saliva sample spiked with 50,100 and $250 \mathrm{ng} / \mathrm{mL}$ of carbonyls and $0.05,0.5$ and $1 \mathrm{ng} / \mathrm{mL}$ of isoprostanes and prostanoids. The recovery was calculated as the percentage ratio of the difference between the analyte concentrations measured in the spiked and the non-spiked samples to the concentration in spiked samples.

Intra- and inter-day precision was expressed as relative standard deviation (RSD\%) of measurements performed on the spiked samples in a single day and on three consecutive days, respectively. The matrix effect was evaluated by comparing the slopes of the calibration curves obtained with working solutions and spiked saliva samples at a confidence level of $95 \%$.

A two-tailed $p$-value of $<0.05$ was considered statistically significant. All data were analyzed using GraphPad Prism (v. 8.0) from GraphPad Software Inc. (La Jolla, USA) and MetaboAnalyst 4.0 (https://www.metaboanalyst.ca).

\section{Results and discussion}

\subsection{Optimization of the extraction procedure for the determination of carbonyls in saliva samples}

Aliquots $(0.2 \mathrm{~mL})$ of pooled saliva sample spiked with $100 \mathrm{ng} / \mathrm{mL}$ of carbonyls were derivatized in triplicate with $0.2 \mathrm{~mL}$ of 2,4-DNPH $\left(12 \mathrm{mM}\right.$ ) for $60 \mathrm{~min}$ at $30{ }^{\circ} \mathrm{C}$. Then, liquid-liquid extraction (LLE), salting-out liquid-liquid extraction (SALLE) and ultra-filtration (UF) with a $3 \mathrm{kDa}$ cut-off were compared in terms of recovery and simplicity of the analytical workflow. An aliquot $(0.4 \mathrm{~mL})$ of hexane was added to the derivatized sample and the resulting mixture was vortex-mixed for $30 \mathrm{~s}$ at $12500 \mathrm{rpm}$. After separation and evaporation of the organic phase, the extract was reconstituted with $0.05 \mathrm{~mL}$ of a water/acetonitrile mixture $(65: 35 \mathrm{v} / \mathrm{v})$ and then injected into the UHPLC-DAD instrument. Single and multiple extractions were compared to optimize the LLE method. For a single extraction, analytes recovery ranged between 70 and $80 \%$ (RSD 15\%) whereas the second extraction did not significantly increase recovery. Salting-out liquid-liquid extraction approach was tested in order to simplify the sample treatment. This approach exploits the principle that the solubility of organic solvent in the water phase can be modulated by modifying the ionic strength of the medium. Magnesium sulfate ( $5 \mathrm{M}$ ) and ammonium formate (5 M), two of the most common inorganic salts used in this field [55], showed a limited capability to separate acetonitrile layer, leading to a poor analytes recovery (40-50\%, RSD 13\%). Taking into account the low molecular weight and high hydrophilicity of the target analytes, the possibility to ultrafiltrate the sample ( $12500 \mathrm{rpm}$ for $25 \mathrm{~min}$ at $4{ }^{\circ} \mathrm{C}$ ) with a molecular weight cut-off of $3 \mathrm{kDa}$ was tested. The experiments were conducted using $0.2 \mathrm{~mL}$ of a pooled saliva sample spiked with $100 \mathrm{ng} / \mathrm{mL}$ of carbonyls. Data highlighted an almost quantitative recovery (90-100\%, RSD 5\%) for all the analytes, with the exception of 2pentanone and hexanal that showed a slightly lower recovery $(80 \%$, RSD 6\%), probably due to their affinity with the plastic material of the device [56]. Thus, the ultra-filtration method was selected according to the highest recovery and high-throughput of this approach compared to the classical LLE.

\subsection{Optimization of MEPS extraction procedure for the determination of} isoprostanes and prostanoids in saliva samples

Compared to the standard SPE approach, MEPS has the main advantage to reduce the amount of sample and solvents needed for the analyte extraction without spoiling the pre-concentration factor [57]. The presence of mucins and other proteins does not allow the direct loading of saliva into the MEPS, thus ultra-filtration (3 kDa cut-off), protein precipitation and sample dilution with water as treatments to minimize the saliva viscosity and preserve the lifetime of the MEPS cartridge were comparatively tested. The experiments were carried out 
Table 2

Calibration range, slope and limits of detection (LOD) of the target compounds.

\begin{tabular}{|c|c|c|c|c|}
\hline Analyte & Calibration range $(\mathrm{ng} / \mathrm{mL})$ & Slope $\left(\mathrm{RSD}^{\mathrm{a}}\right)$ & $\mathrm{R}^{2}$ & $\mathrm{LOD}(\mathrm{ng} / \mathrm{mL})$ \\
\hline Acetone & $25-250$ & $0.202(7 \%)$ & 0.995 & 6 \\
\hline 2-Butanone & $25-250$ & $0.238(7 \%)$ & 0.997 & 2 \\
\hline 2-Pentanone & $25-250$ & $0.310(8 \%)$ & 0.998 & 3 \\
\hline Propanal & $25-250$ & $0.289(6 \%)$ & 0.997 & 1 \\
\hline Butanal & $25-250$ & $0.136(10 \%)$ & 0.994 & 2 \\
\hline Hexanal & $25-250$ & $0.068(12 \%)$ & 0.997 & 2 \\
\hline Acrolein & $25-250$ & $0.509(6 \%$ & 0.999 & 1 \\
\hline Methacrolein & $25-250$ & $0.306(8 \%)$ & 0.997 & 1 \\
\hline Glyoxal & $25-250$ & $0.419(10 \%)$ & 0.995 & 3 \\
\hline Methylglyoxal & $25-250$ & $0.979(13 \%)$ & 0.996 & 2 \\
\hline $15-\mathrm{F}_{2 \mathrm{t}}$-IsoP & $0.05-1$ & $4.0 \times 10^{5}(5 \%)$ & 0.999 & 0.01 \\
\hline $15-\mathrm{E}_{2 \mathrm{t}}$-IsoP & $0.05-1$ & $1.7 \times 10^{5}(6 \%)$ & 0.999 & 0.005 \\
\hline $\mathrm{PGE}_{2}$ & $0.05-1$ & $1.7 \times 10^{5}(8 \%)$ & 0.999 & 0.005 \\
\hline 20-epi-20-F $\mathrm{F}_{4 \mathrm{t}}$-NeuroP & $0.05-1$ & $2.1 \times 10^{4}(10 \%)$ & 0.995 & 0.2 \\
\hline $20-\mathrm{F}_{4 \mathrm{t}}-\mathrm{NeuroP}$ & $0.05-1$ & $1.3 \times 10^{4}(8 \%)$ & 0.999 & 0.08 \\
\hline $7(R, S)$-ST- $\Delta^{8}$-11-dihomo-IsoF & $0.05-1$ & $3.4 \times 10^{5}(9 \%)$ & 0.996 & 0.2 \\
\hline ent-7 $(R, S)-7-\mathrm{F}_{2 \mathrm{t}}$-dihomo-IsoP & $0.05-1$ & $6.4 \times 10^{4}(3 \%)$ & 0.997 & 0.05 \\
\hline $17-\mathrm{F}_{2 \mathrm{t}}$-dihomo-IsoP & $0.05-1$ & $6.7 \times 10^{4}(9 \%)$ & 0.997 & 0.06 \\
\hline
\end{tabular}

a Calculated from three calibration curves.

using $0.5 \mathrm{~mL}$ of pooled saliva sample spiked with 200 and $50 \mathrm{pg} / \mathrm{mL}$ of isoprostanes and prostanoids. Ultra-filtration with a $3 \mathrm{kDa}$ cut-off at $12500 \mathrm{rpm}$ and $4{ }^{\circ} \mathrm{C}$ for $60 \mathrm{~min}$ gave the worst performances showing a very low recovery of $20-30 \%$ (RSD $10 \%$ ) for all the analytes, probably due to the interaction between the plastic material and target chemicals, as already mentioned [56,58]. Protein precipitation with acetonitrile (acetonitrile/saliva volume ratio of 1) entailed an almost quantitative recovery (95-100\%, RSD 10\%) for all the compounds and represents an alternative strategy for the pre-treatment of the sample, confirming the results reported elsewhere [59]. Nevertheless, fast and easy-to-use dilution of the sample with water (water/saliva volume ratio of 6) was preferred to protein precipitation, in order to avoid the evaporation step required for the reduction of the organic phase content before MEPS loading [60]. Lower water-to-saliva ratios (i.e. 3 or 1) were soon excluded because of frequent sorbent occlusion just after ten MEPS extractions. Regarding the recovery of analytes from MEPS, no

Table 3

Recovery, intra- and inter-day precision relevant for the measurement of carbonyls, isoprostanes and prostanoids compounds in spiked pooled saliva samples.

\begin{tabular}{|c|c|c|c|c|}
\hline Analyte & Recovery (\%) & $\begin{array}{l}\text { Intra-day }^{\mathrm{a}} \\
\mathrm{RSD}\end{array}$ & Recovery (\%) & $\begin{array}{l}\text { Inter-day } \\
\text { RSD }\end{array}$ \\
\hline Acetone & 95 & $18 \%$ & 98 & $25 \%$ \\
\hline 2-Butanone & 102 & $9 \%$ & 98 & $13 \%$ \\
\hline 2-Pentanone & 79 & $11 \%$ & 82 & $10 \%$ \\
\hline Propanal & 86 & $5 \%$ & 89 & $7 \%$ \\
\hline Butanal & 94 & $11 \%$ & 95 & $13 \%$ \\
\hline Hexanal & 82 & $16 \%$ & 85 & $17 \%$ \\
\hline Acrolein & 107 & $3 \%$ & 103 & $5 \%$ \\
\hline Methacrolein & 104 & $6 \%$ & 99 & $9 \%$ \\
\hline Glyoxal & 97 & $12 \%$ & 98 & $11 \%$ \\
\hline Methylglyoxal & 91 & $12 \%$ & 93 & $14 \%$ \\
\hline $15-\mathrm{F}_{2 \mathrm{t}}$-IsoP & 116 & $9 \%$ & 117 & $7 \%$ \\
\hline $15-E_{2 t}$-IsoP & 117 & $4 \%$ & 112 & $9 \%$ \\
\hline $\mathrm{PGE}_{2}$ & 123 & $11 \%$ & 116 & $13 \%$ \\
\hline 20-epi-20- $\mathrm{F}_{4 \mathrm{t}}-$ NeuroP & 116 & $15 \%$ & 119 & $11 \%$ \\
\hline $20-\mathrm{F}_{4 \mathrm{t}}-$ NeuroP & 110 & $3 \%$ & 117 & $5 \%$ \\
\hline $\begin{array}{r}7(R, S)-S T-\Delta^{8}-11- \\
\text { dihomo-IsoF }\end{array}$ & 225 & $6 \%$ & 240 & $7 \%$ \\
\hline $\begin{array}{r}\text { ent-7 }(R, S)-7-\mathrm{F}_{2 \mathrm{t}^{-}} \\
\text {dihomo-IsoP }\end{array}$ & 211 & $4 \%$ & 216 & $8 \%$ \\
\hline $17-\mathrm{F}_{2 \mathrm{t}}$-dihomo-IsoP & 208 & $10 \%$ & 198 & $12 \%$ \\
\hline
\end{tabular}

${ }^{\text {a }}$ Calculated from three replicates at each concentration level.

b Calculated from three replicates at each concentration level and on three consecutive days. loss of the analytes during the washing step with $100 \mu \mathrm{L}$ of $\mathrm{MeOH}$ :water 95:5 v/v neither carry over effect were observed for all the analytes investigated. A complete analyte elution was achieved by a single withdraw-eject cycle with $50 \mu \mathrm{L}$ of methanol. The elution with a second aliquot of methanol did not produce any detectable chromatographic signal. The fast and easy-to-use MEPS procedure resulted very innovative. The procedure was semi-automated, highly reproducible (RSD $<5 \%$ ) and accurate (recovery $>90 \%$ ). Compared to time consuming, tedious and multistage procedures reported in literature $[58,61]$, our approach entails saliva clean-up and analyte pre-concentration in about $30 \mathrm{~min}$ by using a reduced amount of organic solvents (i.e. 50-100 $\mu \mathrm{L}$ ). The eluate was directly injected into the UHPLC system without any additional drying step, ensuring the straightforward 10 -fold enrichment of the analyte.

\subsection{Analytical figures of merit}

\subsubsection{Limits of detection and calibration curves}

Table 2 reports calibration range, slope of the calibration curves and limits of detection for the investigated compounds.

As reported in Table 2, detection limits in the range 1-3 $\mathrm{ng} / \mathrm{mL}$ were observed for carbonyls, except for acetone $(6 \mathrm{ng} / \mathrm{mL})$. As for isoprostanes and prostanoids, the limits of detection were in the range $0.005-0.2 \mathrm{ng} / \mathrm{mL}$ and allowed to assess oxidative damage across human health outcomes [62]. The LODs were much lower than those reported in literature [63-65], as in the case of $15-\mathrm{E}_{2 \mathrm{t}}-\mathrm{IsoP}$ and $\mathrm{PGE}_{2}$, whose LODs were as low as $0.01 \mathrm{ng} / \mathrm{mL}$. Only Peña-Bautista et al. reported lower limits of detection (0.01-0.02 ng/mL) for $\mathrm{F}_{2 \mathrm{t}}$-dihomo-IsoPs and $\mathrm{F}_{2 \mathrm{t}}$-dihomo-IsoFs [61]. Finally, the five-points calibration curves $(\mathrm{n}=3$ of each concentration level) of all the investigated analytes showed a coefficient of determination $\left(\mathrm{R}^{2}\right)$ higher than 0.995 , indicating a good linearity over the tested concentration range.

\subsubsection{Recovery and precision}

The analytes recovery and the corresponding intra- and inter-day RSD values are reported in Table 3.

Analyte recovery was not significantly influenced $(p>0.05)$ by concentration level and was satisfactory for most of the analytes when performing both intra- (overall range: 79-123\%) and inter-day (overall range: 82-119\%) experiments (Table 3). For acetone, 2-butanone, butanal, hexanal, acrolein and methacrolein, the recovery was also confirmed by comparing the peak area of both standard solution and spiked saliva samples with those observed by injecting the T011/1P-6A mixture, highlighting that the yield of reaction (\%) was quantitative, as discussed 
Table 4

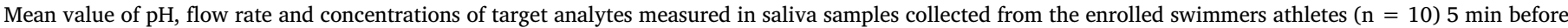

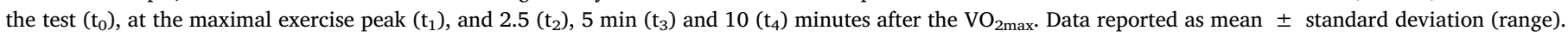

\begin{tabular}{|c|c|c|c|c|c|}
\hline \multirow[t]{2}{*}{ Characteristics } & \multicolumn{5}{|l|}{ Value } \\
\hline & $\mathrm{t}_{0}$ & $\mathrm{t}_{1}$ & $\mathrm{t}_{2}$ & $t_{3}$ & $\mathrm{t}_{4}$ \\
\hline $\mathrm{pH}$ & $\begin{array}{l}6.8 \pm 0.3 \\
(6.3-7.2)\end{array}$ & $\begin{array}{l}6.8 \pm 0.4 \\
(6.1-7.6)\end{array}$ & $\begin{array}{l}6.8 \pm 0.4 \\
(6.1-7.4)\end{array}$ & $\begin{array}{l}6.9 \pm 0.4 \\
(6.5-7.4)\end{array}$ & $\begin{array}{l}6.9 \pm 0.3 \\
(6.5-7.4)\end{array}$ \\
\hline Flow rate $(\mathrm{mL} / \mathrm{min})$ & $1.2 \pm 0.5(0.7-2.0)$ & $\begin{array}{l}1.1 \pm 0.3 \\
(0.6-1.5)\end{array}$ & $\begin{array}{l}1.2 \pm 0.5 \\
(0.6-1.9)\end{array}$ & $\begin{array}{l}1.2 \pm 0.5 \\
(0.5-1.9)\end{array}$ & $\begin{array}{l}1.2 \pm 0.4 \\
(0.6-1.8)\end{array}$ \\
\hline Acetone $(\mathrm{ng} / \mathrm{mL})$ & $\begin{array}{l}150 \pm 108 \\
(125-250)\end{array}$ & $\begin{array}{l}415 \pm 152 \\
(350-560)\end{array}$ & $\begin{array}{l}355 \pm 138 \\
(245-453)\end{array}$ & $\begin{array}{l}235 \pm 112 \\
(165-320)\end{array}$ & $\begin{array}{l}175 \pm 101 \\
(110-220)\end{array}$ \\
\hline 2-Butanone (ng/mL) & $\begin{array}{l}15 \pm 18 \\
(2-50)\end{array}$ & $\begin{array}{l}60 \pm 40 \\
(22-116)\end{array}$ & $\begin{array}{l}82 \pm 56 \\
(11-170)\end{array}$ & $\begin{array}{l}54 \pm 44 \\
(23-125)\end{array}$ & $\begin{array}{l}57 \pm 24 \\
(29-80)\end{array}$ \\
\hline 2-Pentanone (ng/mL) & $\begin{array}{l}99 \pm 35 \\
(50-133)\end{array}$ & $\begin{array}{l}197 \pm 93 \\
(102-334)\end{array}$ & $\begin{array}{l}234 \pm 113 \\
(110-401)\end{array}$ & $\begin{array}{l}180 \pm 85 \\
(78-310)\end{array}$ & $\begin{array}{l}203 \pm 70 \\
(156-307)\end{array}$ \\
\hline Propanal (ng/mL) & $\begin{array}{l}5 \pm 1 \\
(3-6)\end{array}$ & $\begin{array}{l}13 \pm 5 \\
(8-21)\end{array}$ & $\begin{array}{l}12 \pm 5 \\
(4-20)\end{array}$ & $\begin{array}{l}8 \pm 3 \\
(4-11)\end{array}$ & $\begin{array}{l}6 \pm 4 \\
(4-9)\end{array}$ \\
\hline Butanal (ng/mL) & $\begin{array}{l}9 \pm 3 \\
(4-12)\end{array}$ & $\begin{array}{l}14 \pm 5 \\
(10-25)\end{array}$ & $\begin{array}{l}10 \pm 4 \\
(6-15)\end{array}$ & $\begin{array}{l}14 \pm 11 \\
(6-32)\end{array}$ & $\begin{array}{l}9 \pm 4 \\
(6-14)\end{array}$ \\
\hline Hexanal (ng/mL) & $<$ LOD & $<\mathrm{LOD}$ & $<$ LOD & $<$ LOD & $<$ LOD \\
\hline Acrolein (ng/mL) & $<$ LOD & $<$ LOD & $<$ LOD & $<$ LOD & $<$ LOD \\
\hline Methacrolein (ng/mL) & $<$ LOD & $<$ LOD & $<$ LOD & $<$ LOD & $<$ LOD \\
\hline Glyoxal (ng/mL) & $\begin{array}{l}57 \pm 35 \\
(16-112)\end{array}$ & $\begin{array}{l}76 \pm 24 \\
(50-115)\end{array}$ & $\begin{array}{l}85 \pm 40 \\
(25-128)\end{array}$ & $\begin{array}{l}72 \pm 28 \\
(16-125)\end{array}$ & $\begin{array}{l}73 \pm 22 \\
(13-95)\end{array}$ \\
\hline Methylglyoxal (ng/mL) & $\begin{array}{l}12 \pm 9 \\
(2-22)\end{array}$ & $\begin{array}{l}20 \pm 5 \\
(17-30)\end{array}$ & $\begin{array}{l}25 \pm 16 \\
(2-48)\end{array}$ & $\begin{array}{l}25 \pm 24 \\
(4-57)\end{array}$ & $\begin{array}{l}19 \pm 18 \\
(5-45)\end{array}$ \\
\hline $15-\mathrm{F}_{2 \mathrm{t}}$-IsoP (pg/mL) & $\begin{array}{l}14 \pm 6 \\
(9-23)\end{array}$ & $\begin{array}{l}17 \pm 7 \\
(10-26)\end{array}$ & $\begin{array}{l}12 \pm 1 \\
(11-13)\end{array}$ & $\begin{array}{l}11 \pm 2 \\
(10-14)\end{array}$ & $\begin{array}{l}14 \pm 2 \\
(11-16)\end{array}$ \\
\hline $15-\mathrm{E}_{2 \mathrm{t}}$-IsoP (pg/mL) & $<$ LOD & $<$ LOD & $<$ LOD & $<$ LOD & $<$ LOD \\
\hline $\mathrm{PGE}_{2}(\mathrm{pg} / \mathrm{mL})$ & $\begin{array}{l}48 \pm 43 \\
(14-139)\end{array}$ & $\begin{array}{l}81 \pm 89 \\
(10-309)\end{array}$ & $\begin{array}{l}71 \pm 45 \\
(11-155)\end{array}$ & $\begin{array}{l}73 \pm 51 \\
(7-154)\end{array}$ & $\begin{array}{l}112 \pm 161 \\
(13-495)\end{array}$ \\
\hline 20-epi-20- $\mathrm{F}_{4 \mathrm{t}}$-NeuroP $(\mathrm{pg} / \mathrm{mL})$ & $\begin{array}{l}3198 \pm 1663 \\
(970-4804)\end{array}$ & $\begin{array}{l}1052 \pm 570 \\
(370-1992)\end{array}$ & $\begin{array}{l}666 \pm 290 \\
(322-1153)\end{array}$ & $\begin{array}{l}1630 \pm 757 \\
(822-2321)\end{array}$ & $\begin{array}{l}2131 \pm 1456 \\
(264-4362)\end{array}$ \\
\hline $7(R, S)$-ST- $\Delta^{8}$-11-dihmo-IsoF ${ }^{\mathrm{a}}(\mathrm{pg} / \mathrm{mL})$ & $\begin{array}{l}360 \pm 166 \\
(223-684)\end{array}$ & $\begin{array}{l}277 \pm 104 \\
(185-403)\end{array}$ & $\begin{array}{l}295 \pm 119 \\
(205-429)\end{array}$ & $\begin{array}{l}296 \pm 10 \\
(285-305)\end{array}$ & $\begin{array}{l}197 \pm 28 \\
(178-217)\end{array}$ \\
\hline
\end{tabular}

a Analyte concentration was estimated using spiked saliva samples calibration curve.

elsewhere [66]. An overestimated recovery up to about $200 \%$ was obtained for compounds belonging to the families of $\mathrm{F}_{2 \mathrm{t}}$-dihomo-IsoPs and $\mathrm{F}_{2 \mathrm{t}}$-dihomo-IsoFs (Table 3 ) and eluting at the end of the chromatographic run of method 2. These results suggested the presence of matrix effect giving rise to enhancement of the signal, as reported elsewhere [67].

The calculation of the overall intra- and inter-day RSD showed a satisfactory precision that was always lower than or equal to $17 \%$, except for acetone with a value that reached up to $25 \%$ (Table 3 ).

\subsubsection{Interferences and matrix effect}

The shape and position of the analyte peaks were not affected by the presence of the saliva sample, which suggests the absence of any detectable matrix effect. This aspect was definitely confirmed by comparing the slopes of the calibration curves obtained with working solutions and spiked pooled saliva samples. For most of the analytes investigated, the slopes were not significantly different at a confidence level of $95 \%$. The difference became strongly significant for $7(R, S)$-ST$\Delta^{8}$-11-dihomo-IsoF, ent-7 $(R, S)-7-\mathrm{F}_{2 \mathrm{t}}$-dihomo-IsoP and $17-\mathrm{F}_{2 \mathrm{t}}$-dihomoIsoP, with slopes of the "matrix" curves 2 -fold higher than those of "solvent" curves due to a broad ion enhancement effect. The presence of ion enhancement, as already described by Sánchez-Illana et al. [63] and Peña Bautista et al. [61], led to an inaccurate quantitation of such analytes, unless of the use of the standard addition approach [68] or the employment of an analogue labelled internal standard [69]. The absence of commercially available deuterated analogues for most of these new isoprostanes and the laborious work required for their stereochemical synthesis [70,71] made their accurate quantitation still an open issue. In our opinion, the use of an internal standard different from the analogue, as widely suggested in literature $[63,68,69]$, would not be sufficient to exactly mimic the behavior of the analyte during extraction and analysis, as reported by Chocholoušková et al. [72]. For all these reasons, a qualitative/semi-quantitative determination of $\mathrm{F}_{2 \mathrm{t}^{-}}$
dihomo-IsoPs and $\mathrm{F}_{2 \mathrm{t}}$-dihomo-IsoFs was proposed for the preliminary targeted screening analysis of saliva samples. Only after the assessment of the presence of these compounds in saliva samples and their effective role as potential indicators of OS, additional efforts would be evaluated in order to ensure their accurate quantitation, as already guaranteed for the majority of the analytes investigated.

\subsubsection{Stability}

The stability of standard working solutions was evaluated at room temperature $\left(25 \pm 1{ }^{\circ} \mathrm{C}\right)$ and $4{ }^{\circ} \mathrm{C}$, whereas the stability of saliva samples was also studied at $-80{ }^{\circ} \mathrm{C}$. The initial concentration of the analytes $(t=0 \mathrm{~h})$ was used as the reference values and the stability was evaluated using ANOVA model at a confidence level of 95\%.

The stock solutions of ketones, aldehydes, $\alpha, \beta$-unsaturated aldehydes and di-carbonyls were stable at $4{ }^{\circ} \mathrm{C}$ up to one week, longer storage times (i.e. 1 month) entailed a significant decrease $(-60 \%)$ of aldehydes, $\alpha, \beta$-unsaturated aldehydes and di-carbonyls peak areas due to the high reactivity of such chemicals in water solutions. A slight decrease $(-20 \%)$ of ketones peak area was observed after one month. The standard aqueous working solutions of carbonyls were stable at room temperature and $4{ }^{\circ} \mathrm{C}$ for one day. Once derivatized, the carbonyl2,4-DNPH adducts were stable at both room temperature and $4^{\circ} \mathrm{C}$ up to one week. Carbonyls in saliva were stable at $4{ }^{\circ} \mathrm{C}$ up to one day and one month at $-80{ }^{\circ} \mathrm{C}$, and after one freeze-thaw cycle.

Standard stock solutions of isoprostanes and prostanoids were stable up to 1 month at $-80{ }^{\circ} \mathrm{C}$, whereas standard working solutions were stable within a working day at room temperature and up to 1 week at $4{ }^{\circ} \mathrm{C}$. The methanol extract of saliva samples was stable throughout the duration of a typical sequence of UHPLC-MS/MS analysis (storage in the autosampler for about $24 \mathrm{~h}$ at $4{ }^{\circ} \mathrm{C}$ ). Isoprostanes and prostanoids in saliva were stable after one week at $4{ }^{\circ} \mathrm{C}$ and three months at $-80^{\circ} \mathrm{C}$, and after one freeze-thaw cycle. 


\subsection{Application to real samples: monitoring oxidative stress during an incremental cycle ergometer exercise test}

The optimized procedures were employed to determine by-products of oxidative stress in saliva samples collected from ten swimmers performing an incremental cycle ergometer exercise test of maximal aerobic power. Table 4 reports the salivary characteristics measured in the volunteers' saliva samples before, at the maximal exercise peak and after the exercise session.

2-butanone, 2-pentanone, propanal, butanal, glyoxal, methylglyoxal, $\mathrm{PGE}_{2}, 20$-epi-20-F 4 - - NeuroP and 7(R,S)-ST- $\Delta^{8}$-11-dihomo-IsoF were successfully detected in saliva samples of all ten swimmer athletes enrolled, whereas $15-\mathrm{F}_{2 \mathrm{t}}$-IsoP was detected only in three subjects (i.e. V2, V3 and V9). Swimmers showed significantly higher $(p<0.05)$ mean value of propanal measured at the maximal exercise peak $\left(\mathrm{t}_{1}\right)$ $(13 \mathrm{ng} / \mathrm{mL})$ and at $2.5 \mathrm{~min}$ after the $\mathrm{VO}_{2 \max }\left(\mathrm{t}_{2}\right)(12 \mathrm{ng} / \mathrm{mL})$ compared to the level in the sample collected 5 min before the test $(5 \mathrm{ng} / \mathrm{mL})$. Acetone was significantly higher $(p<0.05)$ only at the maximal exercise peak $\left(\mathrm{t}_{1}\right)\left(415 \mathrm{ng} / \mathrm{mL}\right.$ vs $150 \mathrm{ng} / \mathrm{mL}$ at $\left.\mathrm{t}_{0}\right)$. In the same way, salivary levels of 20 -epi-20- $\mathrm{F}_{4 \mathrm{t}}$-NeuroP were significantly decreased $(p<0.05)$ at $\mathrm{t}_{1}$ and $\mathrm{t}_{2}$ compared to the level measured at $\mathrm{t}_{0}$. Butanal and $\mathrm{PGE}_{2}$ showed a slight increase $(p>0.05)$ of the mean value at $t_{1}$, contrarily 2-butanone, 2-pentanone, glyoxal and methylglyoxal showed the highest values at $2.5 \mathrm{~min}$ after the $\mathrm{VO}_{2 \max }\left(\mathrm{t}_{2}\right)$. No significant trend overtime was observed for $15-\mathrm{F}_{2 \mathrm{t}}$-IsoP and $7(R, S)$-ST- $\Delta^{8}-11$-dihomoIsoF. These results are in accordance with the concept that exercise performed at high intensity causes an imbalance between ROS/RNS generation and antioxidant levels, leading to the production of byproducts of oxidative stress [10-12]. According to our results, it has been observed that exercise affects only some oxidative stress markers, as reported in literature [73]. Increasing and/or decreasing trends could be hidden by confounding factors, such as the intensity of the exercise and the training level of the subjects [74]. Thus, saliva analysis was hypothesized to be more effective when performing a longitudinal study, in which each subject acts as his/her own control [34].

Fig. 1 shows the clustering analysis results in the form of heatmap. For each swimmer the variations over time of salivary concentrations of the target analytes were normalized to values measured at the baseline sample $\left(t_{0}\right)$. The purple and red color in the plot represent the highest and lowest value measured, respectively.

All the swimmers showed a remarkable increase (2 to 3-fold) of 2butanone, 2-pentanone and propanal concentration in saliva at $t_{2}$. For all these analytes, a sharp decrease, approaching baseline values, of the salivary levels was observed at $5 \mathrm{~min}\left(\mathrm{t}_{3}\right)$ and $10 \mathrm{~min}\left(\mathrm{t}_{4}\right)$ after the maximal exercise peak $\left(t_{1}\right)$. Thus, these findings suggest that 10 min of active recovery were adequate to restore the balance between radical generation and antioxidants levels, confirming the high fitness level of the enrolled volunteers. Thus, one could speculate that exercise plays a beneficial role against oxidative stress because of its ability to boost up the antioxidant defense mechanisms.

Interestingly, the degree of increase for 2-butanone and 2-pentanone was positively correlated $(p<0.05)$ with the respiratory quotient measured at the peak exercise. Such increase might support the hypothesis that during exercise the human metabolism needs to produce energy from any metabolic source to maintain the physical performance. In addition, the observed correlation points out a direct shift in carbohydrate fatty acid metabolism over the course of performance.

Acetone, glyoxal, methylglyoxal, 20-epi-20- $\mathrm{F}_{4 \mathrm{t}}-\mathrm{NeuroP}$ and $7(R, S)$ ST- $\Delta^{8}$-11-dihomo-IsoF showed different behavior. As an example, the salivary levels of acetone, glyoxal and methylglyoxal did not show significant variation overtime in all the swimmers, whereas for 20-epi$20-\mathrm{F}_{4 \mathrm{t}}$-NeuroP and $7(R, S)$-ST- $\Delta^{8}$-11-dihomo-IsoF a decrease between the baseline level and the exercise peak was observed. Also GarcíaFlores et al. found a reduction of $\mathrm{F}_{2}$-dihomo-IsoP metabolites (i.e. 17$\mathrm{F}_{2 \mathrm{t}}$-dihomo-IsoP and 17-epi-17- $\mathrm{F}_{2 \mathrm{t}}$-dihomo-IsoP) with the increase of a triathlon training [25]. A possible explanation could be that a regular aerobic moderate training could increase the resistance against oxidative stress to favor antioxidant capacity in the brain [75]. These results confirmed the complexity of the metabolic pathways involved in the production of these oxygenated metabolites of polyunsaturated fatty acids.

Our analytical approach allows both to evaluate the epigenetic response to sport in terms of increasing antioxidant systems and to obtain useful information on the severity and evolution of several pathologies such as heart failure and diabetes $[5,6]$.

\section{Conclusions}

This paper reports two validated analytical procedures for the determination of carbonyls, isoprostanes and prostanoids in stimulated saliva samples collected from athletes performing an incremental cycle ergometer exercise test of maximal aerobic power. Overall, our methods showed satisfactory limits of detection (i.e. units of ppb for carbonyls and tens to hundreds of ppt for isoprostanes and prostanoids), quantitative recovery $(90-110 \%)$ and intra- and inter-day precision lower than $15 \%$.

Preliminary results were obtained by monitoring ten swimmers performing a $\mathrm{VO}_{2 \max }$ cycle ergo meter test. A significant increase (3-15fold) of most of the target analytes during exercise with a sharp decrease up to the baseline levels 10 min later the maximal exercise peak was observed. Nevertheless, some inconsistencies of the results were observed, probably due to the training level of the subject and to different eating habits. Moreover, also the large inter-individual variability in exercise-induced oxidative stress may be considered as a confounding factor. Since this large inter-subject variability is not a new concept, we postulated that saliva analysis could be more successful if longitudinal monitoring was performed for each subject over time more than referring to nominal "reference" values. In this way, each subject
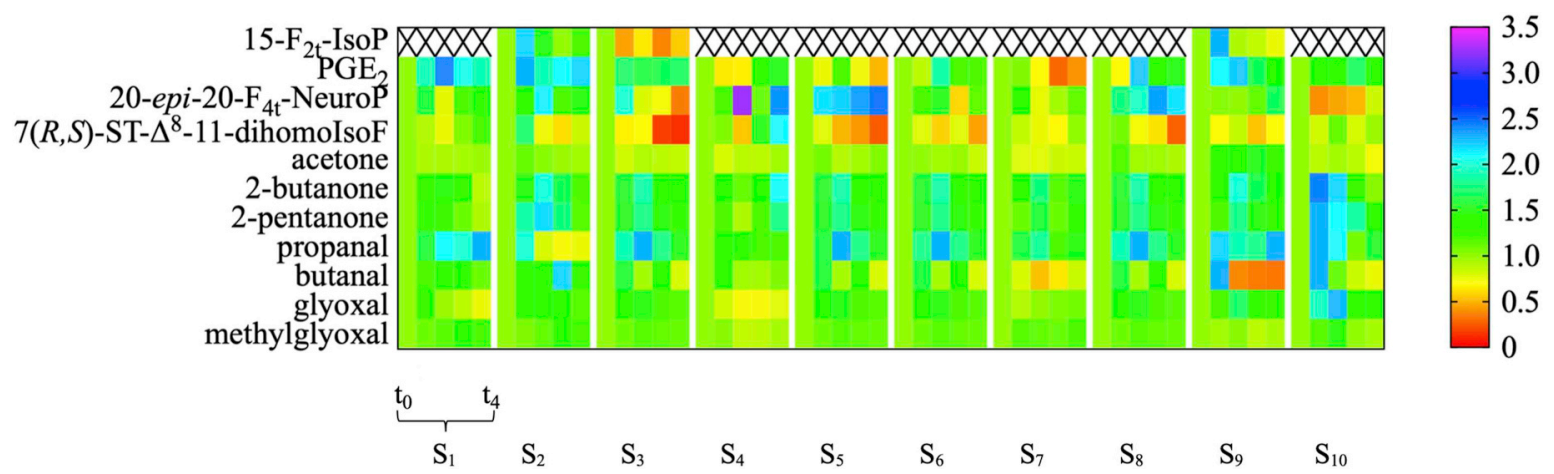

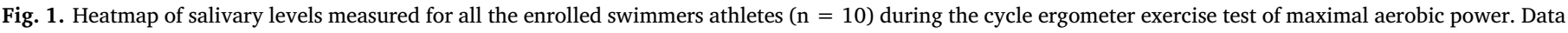
were normalized with respect to the baseline sample $\left(t_{0}\right)$. Each square represents a collection point. 
would act as his/her own control.

These results strongly support the hypothesis that saliva analysis can be used as a non-invasive tool to monitor oxidative stress in patients with various pathologies and in subjects during exercise, helping to obtain useful information on the progress of the disease and on the adaptation to the physical exercise. Further investigations are planned, working on a wider population, in order to increase the statistical power of our results and try to confirm the observed trends.

\section{Funding sources}

This research did not receive any specific grant from funding agencies in the public, commercial, or not for profit sectors.

\section{CRediT authorship contribution statement}

Denise Biagini: Methodology, Validation, Formal analysis, Writing - original draft. Tommaso Lomonaco: Conceptualization, Validation, Formal analysis, Writing - original draft, Writing - review \& editing, Supervision, Project administration. Silvia Ghimenti: Methodology, Validation, Resources. Jonathan Fusi: Formal analysis, Supervision, Project administration. Eugenio Cerri: Formal analysis, Supervision. Francesca De Angelis: Methodology, Writing - original draft. Francesca Giuseppa Bellagambi: Methodology, Writing - original draft. Camille Oger: Formal analysis, Writing - original draft. Jean Marie Galano: Formal analysis, Writing - original draft. Emilia Bramanti: Formal analysis, Writing - review \& editing. Ferdinando Franzoni: Formal analysis, Supervision. Roger Fuoco: Formal analysis, Writing - review \& editing, Supervision, Funding acquisition. Fabio Di Francesco: Formal analysis, Writing - review \& editing, Supervision, Funding acquisition.

\section{Declaration of competing interest}

The authors declare that they have no known competing financial interests or personal relationships that could have appeared to influence the work reported in this paper.

\section{References}

[1] J.S. Aprioku, Pharmacology of free radicals and the impact of reactive oxygen species on the testis, J. Reproduction Infertil. 14 (2013) 158-172.

[2] A. Corti, G. Bergamini, M. Menegazzi, S. Piaggi, E. Bramanti, I. Scataglini, S. Cianchetti, P. Paggiaro, P. Melotti, A. Pompella, $\gamma$-Glutamyltransferase catabolism of S-nitrosoglutathione modulates IL-8 expression in cystic fibrosis bronchia epithelial cells, Free Radic. Biol. Med. 65 (2013) 360-370, https://doi.org/10. 1016/j.freeradbiomed.2013.06.015.

[3] A. Ayer, C.W. Gourlay, I.W. Dawes, Cellular redox homeostasis, reactive oxygen species and replicative ageing in Saccharomyces cerevisiae, FEMS Yeast Res. 14 (2014) 60-72, https://doi.org/10.1111/1567-1364.12114.

[4] D.J. Betteridge, What is oxidative stress? Metabolism 49 (2000) 3-8, https://doi. org/10.1016/S0026-0495(00)80077-3.

[5] P.C. Chikezie, O.A. Ojiako, A.C. Ogbuji, Oxidative stress in diabetes mellitus, Int. J. Biol. Chem. 9 (2015) 92-109, https://doi.org/10.3923/ijbc.2015.92.109.

[6] N.R. Madamanchi, A. Vendrov, M.S. Runge, Oxidative stress and vascular disease, Arterioscler. Thromb. Vasc. Biol. 25 (2005) 29-38, https://doi.org/10.1161/01. ATV.0000150649.39934.13.

[7] B. Halliwell, Reactive oxygen species in living systems: source, biochemistry, and role in human disease, Am. J. Med. 91 (1991) 14S-22S.

[8] E. Bramanti, V. Angeli, Z. Mester, A. Pompella, A. Paolicchi, A. D'Ulivo, Determination of S-nitrosoglutathione in plasma: comparison of two methods, Talanta 81 (2010) 1295-1299, https://doi.org/10.1016/j.talanta.2010.02.024.

[9] E. Bramanti, K. Jacovozzi, L. D'Ulivo, C. Vecoli, R. Zamboni, Z. Mester, A. D'Ulivo, Determination of S-nitrosoglutathione and other nitrosothiols by p-hydroxymercurybenzoate derivatization and reverse phase chromatography coupled with chemical vapor generation atomic fluorescence detection, Talanta 77 (2008) 684-694, https://doi.org/10.1016/j.talanta.2008.07.020.

[10] B.C. Dickinson, C.J. Chang, Chemistry and biology of reactive oxygen species in signaling or stress responses, Nat. Chem. Biol. 7 (2011) 504-511, https://doi.org/ 10.1038/nchembio.607.

[11] E.M. Ellis, Reactive carbonyls and oxidative stress: potential for therapeutic inter vention, Pharmacol. Ther. 115 (2007) 13-24, https://doi.org/10.1016/j. pharmthera.2007.03.015.
[12] P. Montuschi, P.J. Barnes, L.J. Roberts, Isoprostanes: markers and mediators of oxidative stress, Faseb. J. 18 (2004) 1791-1800, https://doi.org/10.1096/fj.042330rev.

[13] D.E.R. Warburton, C.W. Nicol, S.S.D. Bredin, Health benefits of physical activity: the evidence, CMAJ (Can. Med. Assoc. J.) 174 (2006) 801-809, https://doi.org/10 $1503 / \mathrm{cmaj} .051351$.

[14] J. Kruk, Physical activity in the prevention of the most frequent chronic diseases: an analysis of the recent evidence, Asian Pac. J. Cancer Prev. APJCP 8 (2007) 325-338.

[15] D. Nunan, K.R. Mahtani, N. Roberts, C. Heneghan, Physical activity for the prevention and treatment of major chronic disease: an overview of systematic reviews, Syst. Rev. 56 (2013) 2-6, https://doi.org/10.1186/2046-4053-2-56.

[16] M.A. Bouzid, E. Filaire, R. Matran, S. Robin, C. Fabre, Lifelong voluntary exercise modulates age-related changes in oxidative stress, Int. J. Sports Med. 39 (2018) 21-28, https://doi.org/10.1055/s-0043-119882.

[17] T.T. Peternelj, J.S. Coombes, Antioxidant supplementation during exercise training: beneficial or detrimental? Sports Med. 41 (2011) 1043-1069, https://doi.org/10. 2165/11594400-000000000-00000.

[18] C. Simioni, G. Zauli, A.M. Martelli, M. Vitale, G. Sacchetti, A. Gonelli, L.M. Neri, Oxidative stress: role of physical exercise and antioxidant nutraceuticals in adulthood and aging, Oncotarget 9 (2018) 17181-17198, https://doi.org/10.18632/ oncotarget.24729.

[19] M.B. Reid, Nitric oxide, reactive oxygen species, and skeletal muscle contraction, Med. Sci. Sports Exerc. 33 (2001) 371-376, https://doi.org/10.1097/00005768200103000-00006.

[20] M.J. Solivio, D.B. Nemera, L. Sallans, E.J. Merino, Biologically relevant oxidants cause bound proteins to readily oxidatively cross-link at Guanine, Chem. Res. Toxicol. 25 (2012) 326-336, https://doi.org/10.1021/tx200376e.

[21] B.G. Hill, A. Bhatnagar, Beyond reactive oxygen species: aldehydes as arbitrators of alarm and adaptation, Circ. Res. 105 (2009) 1044-1046, https://doi.org/10.1161/ CIRCRESAHA.109.209791.

[22] M.G. Nikolaidis, A.Z. Jamurtas, V. Paschalis, I.G. Fatouros, Y. Koutedakis, D. Kouretas, The effect of muscle-damaging exercise on blood and skeletal muscle oxidative stress: magnitude and time-course considerations, Sports Med. 38 (2008) 579-606, https://doi.org/10.2165/00007256-200838070-00005.

[23] S. Medina, R. Domínguez-Perles, R. Cejuela-Anta, D. Villaño, J.M. Martínez-Sanz, P. Gil, C. García-Viguera, F. Ferreres, J.I. Gil, A. Gil-Izquierdo, Assessment of oxidative stress markers and prostaglandins after chronic training of triathletes, Prostag. Other Lipid Mediat. 99 (2012) 79-86, https://doi.org/10.1016/j. prostaglandins.2012.07.002.

[24] A. Mastaloudis, S.W. Leonard, M.G. Traber, Oxidative stress in athletes during extreme endurance exercise, Free Radic. Biol. Med. 31 (2001) 911-922, https://doi. org/10.1016/S0891-5849(01)00667-0.

[25] L.A. García-Flores, S. Medina, C. Oger, J.M. Galano, T. Durand, R. Cejuela, J.M. Martínez-Sanz, F. Ferreres, Á. Gil-Izquierdo, Lipidomic approach in young adult triathletes: effect of supplementation with a polyphenols-rich juice on neuroprostane and F2-dihomo-isoprostane markers, Food Funct 7 (2016) 4343-4355, https://doi.org/10.1039/c6fo01000h.

[26] L.A. García-Flores, S. Medina, R. Cejuela, J.M. Martínez-Sanz, C. Oger, J.M. Galano, T. Durand, T. Casas-Pina, P. Martínez-Hernández, F. Ferreres, Á. Gil-Izquierdo, Assessment of oxidative stress biomarkers - neuroprostanes and dihomo-isoprostanes - in the urine of elite triathletes after two weeks of moderate-altitude training, Free Radic. Res. 50 (2016) 485-494, https://doi.org/10.3109/10715762. 2015.1111514

[27] J.L. Watters, J.A. Satia, L.L. Kupper, Correlates of antioxidant nutrients and oxidative DNA damage differ by race in a cross-sectional study of healthy African American and white adults, Nutr. Res. 28 (2008) 565-576, https://doi.org/10. 1016/j.nutres.2008.06.005.

[28] R. Deminice, T. Sicchieri, P.O. Payão, A.A. Jordão, Blood and salivary oxidative stress biomarkers following an acute session of resistance exercise in humans, Int. J. Sports Med. 31 (2010) 599-603, https://doi.org/10.1055/s-0030-1255107.

[29] D. González, R. Marquina, N. Rondón, A.J. Rodríguez-Malaver, R. Reyes, Effects of aerobic exercise on uric acid, total antioxidant activity, oxidative stress, and nitric oxide in human saliva, Res. Sports Med. 16 (2008) 128-137, https://doi.org/10. 1080/15438620802103700.

[30] C. Santone, V. Dinallod, M. Paci, S. D'Ottavio, G. Barbato, S. Bernardini, Saliva metabolomics by NMR for the evaluation of sport performance, J. Pharmaceut. Biomed. Anal. 88 (2014) 441-446, https://doi.org/10.1016/j.jpba.2013.09.021.

[31] E. Papacosta, G.P. Nassis, Saliva as a tool for monitoring steroid, peptide and immune markers in sport and exercise science, J. Sci. Med. Sport 14 (2011) 424-434, https://doi.org/10.1016/j.jsams.2011.03.004.

[32] M. Onor, S. Gufoni, T. Lomonaco, S. Ghimenti, P. Salvo, F. Sorrentino, E. Bramanti, Potentiometric sensor for non invasive lactate determination in human sweat, Anal Chim. Acta 989 (2017) 80-87, https://doi.org/10.1016/j.aca.2017.07.050.

[33] F.G. Bellagambi, I. Degano, S. Ghimenti, T. Lomonaco, V. Dini, M. Romanelli, F. Mastorci, A. Gemignani, P. Salvo, R. Fuoco, F. Di Francesco, Determination of salivary $\alpha$-amylase and cortisol in psoriatic subjects undergoing the Trier Social Stress Test, Microchem. J. 136 (2018) 177-184, https://doi.org/10.1016/j.microc. 2017.04.033.

[34] D. Biagini, T. Lomonaco, S. Ghimenti, F.G. Bellagambi, M. Onor, M.C. Scali, V. Barletta, M. Marzilli, P. Salvo, M.G. Trivella, R. Fuoco, F. Di Francesco, Determination of volatile organic compounds in exhaled breath of heart failure patients by needle trap micro-extraction coupled with gas chromatography-tandem mass spectrometry, J. Breath Res. 11 (2017) 047110, , https://doi.org/10.1088/ 1752-7163/aa94e7.

[35] B. Campanella, M. Onor, T. Lomonaco, E. Benedetti, E. Bramanti, HS-SPME-GC-MS approach for the analysis of volatile salivary metabolites and application in a case 
study for the indirect assessment of gut microbiota, Anal. Bioanal. Chem. 411 (2019) 7551-7562, https://doi.org/10.1007/s00216-019-02158-6.

[36] S. Ghimenti, T. Lomonaco, M. Onor, L. Murgia, A. Paolicchi, R. Fuoco, L. Ruocco, G. Pellegrini, M.G. Trivella, F. Di Francesco, Measurement of Warfarin in the Oral Fluid of Patients Undergoing, Anticoagulant Oral Therapy vol. 6, (2011) e28182, , https://doi.org/10.1371/journal.pone.0028182.

[37] T. Lomonaco, S. Ghimenti, I. Piga, D. Biagini, M. Onor, R. Fuoco, A. Paolicchi, L. Ruocco, G. Pellegrini, M.G. Trivella, F. Di Francesco, Monitoring of warfarin therapy: preliminary results from a longitudinal pilot study, Microchem. J. 136 (2018) 170-176, https://doi.org/10.1016/j.microc.2017.02.010.

[38] J.K.M. Aps, L.C. Martens, Review: the physiology of saliva and transfer of drugs into saliva, Forensic Sci. Int. 150 (2005) 119-131, https://doi.org/10.1016/j.forsciint. 2004.10.026.

[39] M. Navazesh, Methods for collecting saliva, Ann. N. Y. Acad. Sci. 694 (1993) 72-77, https://doi.org/10.1111/j.1749-6632.1993.tb18343.x.

[40] F.G. Bellagambi, T. Lomonaco, P. Salvo, F. Vivaldi, M. Hangouët, S. Ghimenti, D. Biagini, F. Di Francesco, R. Fuoco, A. Errachid, Saliva sampling: methods and devices. An overview, TrAC Trends Anal. Chem. (Reference Ed.) 124 (2020) 115781, https://doi.org/10.1016/j.trac.2019.115781.

[41] C. Oger, Y. Brinkmann, S. Bouazzaoui, T. Durand, J.M. Galano, Stereocontrolled access to isoprostanes via a bicyclo[3.3.0]octene framework, Org. Lett. 10 (2008) 5087-5090, https://doi.org/10.1021/ol802104z.

[42] C. Oger, V. Bultel-Poncé, A. Guy, T. Durand, J.M. Galano, Total synthesis of isoprostanes derived from adrenic acid and EPA, Eur. J. Org Chem. 93 (2012) 52-60, https://doi.org/10.1002/ejoc.201200070.

[43] A. De La Torre, Y.Y. Lee, C. Oger, P.T. Sangild, T. Durand, J.C.Y. Lee, J.M. Galano, Synthesis, discovery, and quantitation of dihomo-isofurans: biomarkers for in vivo adrenic acid peroxidation, Angew. Chem. Int. Ed. 53 (2014) 6249-6252, https:// doi.org/10.1002/anie.201402440.

[44] A. De La Torre, Y.Y. Lee, A. Mazzoni, A. Guy, V. Bultel-Poncé, T. Durand, C. Oger, J.C.Y. Lee, J.M. Galano, Total syntheses and in vivo quantitation of novel neurofuran and dihomo-isofuran derived from docosahexaenoic acid and adrenic acid, Chem. Eur J. 21 (2015) 2442-2446, https://doi.org/10.1002/chem.201405497.

[45] H. Adachi, Cardiopulmonary exercise test: the most powerful tool to detect hidden pathophysiology, Int. Heart J. 58 (2017) 654-665, https://doi.org/10.1536/ihj.17264.

[46] A.R. Zamunér, M.A. Moreno, T.M. Camargo, J.P. Graetz, A.C.S. Rebelo, N.Y. Tamburús, E. da Silva, Assessment of subjective perceived exertion at the anaerobic threshold with the Borg CR-10 scale, J. Sports Sci. Med. 10 (2011) $130-136$.

[47] C. Dawes, Circadian rhythms in human salivary flow rate and composition, J. Physiol. 220 (1972) 529-545, https://doi.org/10.1113/jphysiol.1972.sp009721.

[48] H. Patel, A. Bhardwaj, Physiology, respiratory quotient, Statpearls Internet 68 (2018) 1063-1075.

[49] J.L. Chicharro, A. Lucía, M. Pérez, A.F. Vaquero, R. Ureña, Saliva composition and exercise, Sports Med. 26 (1998) 17-27, https://doi.org/10.2165/00007256199826010-00002.

[50] R. Andreoli, P. Manini, M. Corradi, A. Mutti, W.M.A. Niessen, Determination of patterns of biologically relevant aldehydes in exhaled breath condensate of healthy subjects by liquid chromatography/atmospheric chemical ionization tandem mass spectrometry, Rapid Commun. Mass Spectrom. 17 (2003) 637-645, https://doi. org/10.1002/rcm.960.

[51] D. Biagini, S. Antoni, T. Lomonaco, S. Ghimenti, P. Salvo, F.G. Bellagambi, R.T. Scaramuzzo, M. Ciantelli, A. Cuttano, R. Fuoco, F. Di Francesco, Micro-extraction by packed sorbent combined with UHPLC-ESI-MS/MS for the determination of prostanoids and isoprostanoids in dried blood spots, Talanta 206 (2020) 120236, https://doi.org/10.1016/j.talanta.2019.120236.

[52] Commission Decision, 2002/657/EC Commission Decision of 12 August 2002 implementing Council Directive 96/23/EC concerning the performance of analytical methods and the interpretation of results, Off. J. Eur. Communities (2002).

[53] M. Thompson, S.L.R. Ellison, R. Wood, Harmonized guidelines for single-laboratory validation of methods of analysis (IUPAC Technical Report), Pure Appl. Chem. 74 (2002) 835-855, https://doi.org/10.1351/pac200274050835.

[54] K. Linnet, Performance of Deming regression analysis in case of misspecified analytical error ratio in method comparison studies, Clin. Chem. 44 (1998) 1024-1031.

[55] Y.Q. Tang, N. Weng, Salting-out assisted liquid-liquid extraction for bioanalysis, Bioanalysis 5 (2013) 1583-1589, https://doi.org/10.4155/bio.13.117.

[56] T. Lomonaco, S. Ghimenti, I. Piga, M. Onor, B. Melai, R. Fuoco, F. Di Francesco, Determination of total and unbound warfarin and warfarin alcohols in human plasma by high performance liquid chromatography with fluorescence detection, J. Chromatogr., A 1314 (2013) 54-62, https://doi.org/10.1016/j.chroma.2013.08. 091.

[57] C. Silva, C. Cavaco, R. Perestrelo, J. Pereira, J.S. Câmara, Microextraction by packed Sorbent (MEPS) and solid-phase microextraction (SPME) as sample preparation procedures for the metabolomic profiling of urine, Metabolites 4 (2014) 71-97, https://doi.org/10.3390/metabo4010071.
[58] J. Figueira, S. Gouveia-Figueira, C. Öhman, P. Lif Holgerson, M.L. Nording, A. Öhman, Metabolite quantification by NMR and LC-MS/MS reveals differences between unstimulated, stimulated, and pure parotid saliva, J. Pharmaceut. Biomed. Anal. 140 (2017) 295-300, https://doi.org/10.1016/j.jpba.2017.03.037.

[59] A.E. Mendonza, R.Y. Gohh, F. Akhlaghi, Analysis of mycophenolic acid in saliva using liquid chromatography tandem mass spectrometry, Ther. Drug Monit. 28 (2006) 402-406, https://doi.org/10.1097/01.ftd.0000211826.65607.05.

[60] P. Sibiya, M. Potgieter, E. Cukrowska, J.A.. Jönsson, L. Chimuka, Development and application of solid phase extraction method for polycyclic aromatic hydrocarbons in water samples in Johannesburg area, South Africa, S, Afr. J. Chem. 65 (2012) in water sa6-213.

[61] C. Peña-Bautista, P. Carrascosa-Marco, C. Oger, C. Vigor, J.M. Galano, T. Durand, M. Baquero, M. López-Nogueroles, M. Vento, A. García-Blanco, C. Cháfer-Pericás, Validated analytical method to determine new salivary lipid peroxidation compounds as potential neurodegenerative biomarkers, J. Pharmaceut. Biomed. Anal. 164 (2019) 742-749, https://doi.org/10.1016/j.jpba.2018.11.043.

[62] T.J. van 't Erve, M.B. Kadiiska, S.J. London, R.P. Mason, Classifying oxidative stress by F2-isoprostane levels across human diseases: a meta-analysis, Redox Biol 12 (2017) 582-599, https://doi.org/10.1016/j.redox.2017.03.024.

[63] Á. Sánchez-Illana, S. Thayyil, P. Montaldo, D. Jenkins, G. Quintás, C. Oger, J.M. Galano, C. Vigor, T. Durand, M. Vento, J. Kuligowski, Novel free-radical mediated lipid peroxidation biomarkers in newborn plasma, Anal. Chim. Acta 996 (2017) 88-97, https://doi.org/10.1016/j.aca.2017.09.026.

[64] A. Dupuy, P. Le Faouder, C. Vigor, C. Oger, J.M. Galano, C. Dray, J.C.Y. Lee, P. Valet, C. Gladine, T. Durand, J. Bertrand-Michel, Simultaneous quantitative profiling of 20 isoprostanoids from omega-3 and omega- 6 polyunsaturated fatty acids by LC-MS/MS in various biological samples, Anal. Chim. Acta 921 (2016) 46-58, https://doi.org/10.1016/j.aca.2016.03.024.

[65] K.M. Rund, A.I. Ostermann, L. Kutzner, J.M. Galano, C. Oger, C. Vigor, S. Wecklein, N. Seiwert, T. Durand, N.H. Schebb, Development of an LC-ESI(-)-MS/MS method for the simultaneous quantification of 35 isoprostanes and isofurans derived from the major n3- and n6-PUFAs, Anal. Chim. Acta 1037 (2018) 63-74, https://doi.org/ 10.1016/j.aca.2017.11.002.

[66] S. Uchiyama, Y. Inaba, N. Kunugita, Derivatization of carbonyl compounds with 2,4-dinitrophenylhydrazine and their subsequent determination by high-performance liquid chromatography, J. Chromatogr. B Anal. Technol. Biomed. Life Sci. 879 (2011) 1282-1289, https://doi.org/10.1016/j.jchromb.2010.09.028.

[67] P.J. Taylor, Matrix effects: the Achilles heel of quantitative high-performance liquid chromatography-electrospray-tandem mass spectrometry, Clin. Biochem. 38 (2005) 328-334, https://doi.org/10.1016/j.clinbiochem.2004.11.007.

[68] C. Cháfer-Pericás, L. Rahkonen, A. Sánchez-Illana, J. Kuligowski, I. Torres-Cuevas, M. Cernada, E. Cubells, A. Nuñez-Ramiro, S. Andersson, M. Vento, J. Escobar, Ultra high performance liquid chromatography coupled to tandem mass spectrometry determination of lipid peroxidation biomarkers in newborn serum samples, Anal. Chim. Acta 886 (2015) 214-220, https://doi.org/10.1016/j.aca.2015.06.028.

[69] S. Medina, I. De Miguel-Elízaga, C. Oger, J.M. Galano, T. Durand, M. MartínezVillanueva, M.L.G. Del Castillo, I. Villegas-Martínez, F. Ferreres, P. MartínezHernández, Á. Gil-Izquierdo, Dihomo-isoprostanes - nonenzymatic metabolites of AdA - are higher in epileptic patients compared to healthy individuals by a new ultrahigh pressure liquid chromatography-triple quadrupole-tandem mass spectrometry method, Free Radic. Biol. Med. 79 (2015) 154-163, https://doi.org/10. 1016/j.freeradbiomed.2014.11.005.

[70] C. Oger, V. Bultel-Poncé, A. Guy, L. Balas, J.C. Rossi, T. Durand, J.M. Galano, The handy use of brown's p2-ni catalyst for a skipped diyne deuteration: application to the synthesis of a [D4]-labeled F4t- neuroprostane, Chem. Eur J. 16 (2010) 13976-13980, https://doi.org/10.1002/chem.201002304.

[71] A. Guy, C. Oger, J. Heppekausen, C. Signorini, C. Defelice, A. Fürstner, T. Durand, J.M. Galano, Oxygenated Metabolites of $\mathrm{n}-3$ polyunsaturated fatty acids as potential oxidative stress biomarkers: total synthesis of 8-F3t-IsoP, 10-F 4t-NeuroP and [D4]10-F4t-NeuroP, Chem. Eur J. 20 (2014) 6374-6380, https://doi.org/10.1002/ chem. 201400380.

[72] M. Chocholoušková, R. Jirásko, D. Vrána, J. Gatěk, B. Melichar, M. Holčapek, Reversed phase UHPLC/ESI-MS determination of oxylipins in human plasma: a case study of female breast cancer, Anal. Bioanal. Chem. 411 (2019) 1239-1251, https://doi.org/10.1007/s00216-018-1556-y.

[73] A.M. Knab, D.C. Nieman, N.D. Gillitt, R.A. Shanely, L. Cialdella-Kam, D. Henson, W. Sha, M.P. Meaney, Effects of a freeze-dried juice blend powder on exerciseinduced inflammation, oxidative stress, and immune function in cyclists, Appl. Physiol. Nutr. Metabol. 39 (2014) 381-385, https://doi.org/10.1139/apnm-20130338.

[74] T. Kawamura, I. Muraoka, Exercise-induced oxidative stress and the effects of antioxidant intake from a physiological viewpoint, Antioxidants 7 (2018) E119, https://doi.org/10.3390/antiox7090119.

[75] D. Camiletti-Moirón, V.A. Aparicio, P. Aranda, Z. Radak, Does exercise reduce brain oxidative stress? A systematic review, Scand. J. Med. Sci. Sports 23 (2013) e202-e212, https://doi.org/10.1111/sms.12065. 